Association for Information Systems AIS Electronic Library (AISeL)

GlobDev 2018

Proceedings Annual Workshop of the AIS Special Interest Group for ICT in Global Development

$12-13-2018$

\title{
Influence of Constant Returns to Scale and Variable Returns to Scale Data Envelopment Analysis Models in ICT Infrastructure Efficiency Utilization
}

'Yinka Oyerinde

University of South Africa, 57645752@mylife.unisa.ac.za

Felix Olu Bankole

University of South Africa, bankofo@unisa.ac.za

Follow this and additional works at: https://aisel.aisnet.org/globdev2018

\section{Recommended Citation}

Oyerinde, 'Yinka and Bankole, Felix Olu, "Influence of Constant Returns to Scale and Variable Returns to Scale Data Envelopment Analysis Models in ICT Infrastructure Efficiency Utilization" (2018). GlobDev 2018. 11.

https://aisel.aisnet.org/globdev2018/11 


\title{
Influence of Constant Returns to Scale and Variable Returns to Scale Data Envelopment Analysis Models in ICT Infrastructure Efficiency Utilization
}

\author{
'Yinka Oyerinde \\ University of South Africa \\ 57645752@mylife.unisa.ac.za \\ Felix Bankole \\ University of South Africa \\ bankofo@unisa.ac.za
}

Paper Category: Research Paper

\begin{abstract}
A lot of research has been done using Data Envelopment Analysis (DEA) to measure efficiency in Education. DEA has also been used in the field of Information and Communication Technology for Development (ICT4D) to investigate and measure the efficiency of Information and Communication Technology (ICT) investments on Human Development. Education is one of the major components of the Human Development Index (HDI) which affects the core of Human Development. This research investigates the relative efficiency of ICT Infrastructure Utilization on the educational component of the HDI. A conceptual model taking the form of a Linear Equation was used and the Constant Returns to Scale (CRS) and Variable Returns to Scale (VRS) models of the Data Envelopment Analysis were employed to measure the relative efficiency of the components of ICT Infrastructure (Inputs) and the components of Education (Outputs). Results show a generally high relative efficiency of ICT Infrastructure utilization on Educational Attainment and Adult Literacy rates, a strong correlation between this Infrastructure and Literacy rates as well, provide an empirical support for the argument of increasing ICT infrastructure to provide an increase in Human Development, especially within the educational context.
\end{abstract}

Keywords: ICT4D, Data Envelopment Analysis, ICT Infrastructure, Educational Attainment/Adult Literacy Rates, Human Development Index.

\section{INTRODUCTION}

The application of Data Analytics in Education, otherwise known as Learning Analytics, is currently gaining traction in terms of research interests and investments in technology (Oyerinde \& Chia, 2017). With the considerable successes of Business Intelligence, it is little wonder that Data Analytics has found its way into the Education Sector especially in Information and Communication for Development (ICT4D) research. National development is said to encapsulate 
the notion of human development as the means of enlarging people's choices to acquire knowledge, amongst others, in order to have access to the resources needed for a decent standard of living (UNDP, 2006; Bankole \& Mimbi, 2017). Over the last three decades, the lexicon of national development has been expanded to certain intervening variables and social factors such as education and some other aspects of human welfare. (Desai, 1991; Anand \& Ravallion, 1993; Bankole \& Mimbi, 2017). With Educational Attainment being one of the core indices for measuring Development with respect to the Human Development Index (HDI) (UNDP, 2006; Bankole et al., 2011a; Bankole, 2015), Learning Analytics and other research investigating the educational component of the HDI is relevant and applicable for ICT4D research and potential policy making and implementation.

Data Envelopment Analysis (DEA) is a well known and established methodology used for the assessment of efficiency and performance of organizations (Cooper et al., 2006; Thanassoulis et al., 2008). In the area of education, DEA has been widely used for the assessment of efficiency of the school provision at different levels (Färe et al., 2006; Portela et al., 2012), universities and their departments (Avkiran, 2001; Thanassoulis et al., 2011), and the impact of education policies (Bradley et al., 2001; Grosskopf \& Moutray, 2001). The two conventional models traditionally employed in DEA studies, including applications in education, are based on the Variable Returns to Scale (VRS) and Constant Returns to Scale (CRS) models. Even, if the true (best practice) technology is assumed to be VRS, the reference, or benchmark, CRS technology is often used as a part of the scale efficiency calculations (Podinovski et al., 2014).

However, one of the common challenges in applications of DEA is the low discriminating power of the model used. This is the ability of the DEA models to differentiate between good and bad performing Decision-Making Units (DMUs) by reflecting on their performance in a sufficiently wide range of efficiency scores (Cooper et al., 2007; Thanassoulis et al., 2008; Atici \& Podinovski, 2015). It is well-known that the discrimination of a DEA model depends on a number of factors, including the number of inputs and outputs in relation to the number of units, the type (variable or constant) of returns-to-scale assumed (VRS and CRS, respectively) and, more generally, the particular dataset that is under the investigation (Angulo-Meza \& Lins, 2002; Podinovski \& Thanassoulis 2007). 
In this paper, we aim to investigate the relative efficiency of ICT Infrastructure utilization on Education as a component of National Development using CRS and VRS models of the DEA. Hitherto, countries have defined policies that show an emphasis on creating support mechanisms for the use of ICT, including for example, technical and pedagogical support, putting special attention on the use of ICT in teaching and learning (Hinostroza, 2018). However, in providing and defining these policies, a crucial question policy makers must answer is if increased investments in ICT infrastructure provides any improvement in human development especially for Africa (Bankole et al., 2011b). We also employ the same education index employed by Bankole et al., (2011b) introduced by Orbicom (2005) and International Telecommunications Union (ITU) to emphasize the impact of higher education on ICT development. The rest of the article is organized as follows: Section two provides the background, section three discusses the theoretical framework, section four provides the research methodology and analysis, section five provides discussion of findings, section six provides the limitations and section seven the conclusion and future work.

\section{BACKGROUND}

The need to understand the relevance of education in Human Development cannot be overemphasized. A lot of research postulates that increase in ICT investments and penetration on the continent will bring about a corresponding increase in Human Development (Akpan, 2000; Neumayer, 2001). Bankole et al. (2011b) showed that any empirical investigation with regards to education for ICT4D research, needs to consider higher education as one of the main parameters. ICT facilitates and improves students' knowledge and promotes positive attitude to learning therefore, if students in developing economies are to compete with their counterparts in the developed world, effort must be made to develop their ICT abilities (Olaniyi \& Ademola, 2013). Thus, many Higher Education institutions in the Developing Economies have invested heavily in the use of ICT for teaching and learning i.e. use of mobile and/or home based ICT infrastructure as tools to extend teaching and learning possibilities (Hinostroza, 2018) however, its impact has been minimal (Olaniyi \& Ademola, 2013), despite the differences in the level of ICT development across countries (Hinostroza, 2018). 
DEA has been used to measure efficiency for well over 3 decades and its applications spread over a wide range of thematic areas (Liu et al., 2013a). Some applications such as education and health care blossomed in the early days of DEA, while other applications, on the other hand, have just begun to apply DEA fairly recently (Liu et al., 2013b). A systematic survey on DEA applications was carried out by Liu et al., (2013b) and the results identified education as being one of the top five major application areas of DEA and prominent in its grand development. This is seen in Bessent \& Bessent (1980), Charnes et al. (1981), Bessent et al. (1982), and Bessent et al. (1983). Liu et al., (2013b) discovered that historically, there have been two major groups of DEA applications in Education in the literature. There is the one that studies the efficiency of higher education and that for basic education. The group for higher education includes Bessent et al. (1983), Sinuany-stern et al. (1994), Arcelus and Coleman (1997), Johnes (2006), and Johnes and $\mathrm{Li}$ (2008). The recent trend of efficiency studies in the education category clearly focuses on the higher education sector as articles mostly evaluate the performance of universities (Liu et al., 2013).

In addition, there have been some studies that have used DEA to measure efficiency in education with respect to Human Development. Gupta \& Verhoeven (2001) measured the efficiency of education in Africa and Clements (2002) measured efficiency of education in Europe. St. Aubyn (2002) and Afonso and St. Aubyn (2005, 2006a, 2006b) measured with respect to OECD countries. However, only Tondeur et al., (2007) and Gulbahar, (2008) have examined the efficiency of countries in utilising their ICT resources for educational outputs and the Impact of ICT on education. Recently, Aristovnik, (2012) did a study on the impact of ICT on educational performance and its efficiency in select EU and OECD countries using DEA.

With the potential of educational technologies to positively improve educational quality and attainment, there is great optimism that efficient ICT usage in education can greatly increase both average literacy rates and educational attainment levels in developing economies. However, despite these promises being included in education policies that are related towards achieving a positive impact of ICTs on students' achievements, there is no conclusive evidence to support this especially in developing countries (Hinostroza et al., 2014). This situation has posed new questions 
to the research community and policy makers (Hinostroza, 2018). It is against this backdrop that we carry out this study to investigate the relative efficiency of ICT infrastructure utilization on education with respect to human development using the well established DEA method.

\section{THEORETICAL FRAMEWORK}

Investments in ICT can be thought of as consisting of four facets: hardware, software, internal (investments in labour) spending and telecommunication investments respectively (WITSA, 2008; Bankole et al., 2013). For the purpose of this study we shall look at only three of these aspects which are readily measurable for Infrastructure Utilization. These are:

- Hardware: Here we take data available for percentage of Individuals with Computers

- Software: Here we take data available for percentage of Individuals with Internet

- Telecommunications: Here we take data available for percentage of Individuals with Mobile Phones.

This research uses a conceptual model for measuring the efficiency of ICT Infrastructure on Education and is derived from Bankole et al., (2011b) model for measuring Impact of ICT on Human development which expressed Human Development as:

$H D I=f[$ Standard of living (GDP per capita), Education (Literacy rates / Enrolments) and Health (life expectancy)]

For this research we focus solely on the Education component of Human Development. The conceptual model takes the form of a linear equation derived from Bankole et al., (2011b) model for measuring impact on education within the Human Development Index and can be considered to have similarity to another linear model, the translog production function framework (Ko and Osei-Bryson, 2004; Evans et al., 2000; Berndt and Christensen, 1972), in that it allows for pairwise interactions between the components of ICT. It can be considered to have the following form where E represents the educational component of the human development index (HDI), H represents Hardware Infrastructure, S represents Software Infrastructure, T represents Telecommunication Infrastructure, derived from Bankole et al., (2011d) and expressed as: 


\section{$\log (\boldsymbol{E})=\alpha_{o}+\alpha_{H S} \log (H) * \log (S)+\alpha_{T H} \log (T) * \log (H)+\alpha_{T S} \log (T) * \log (S)+\xi$}

In this model, we are looking at ICT infrastructure available for utilization and not investments made for potential utilization. This model now focuses on educational attainment with adult literacy rates and no longer enrolment. This is because the data collected was for ICT infrastructure available for utilization over the period of time being investigated, 2011-2017, when the various educational levels were attained. Therefore, the model for this study which reflects the above logarithmic expression is:

The impact on Education (Adult Literacy rates / Attainments) $=$ f[Internet Infrastructure (II) + Computer Infrastructure (CI) + Mobile Phone Infrastructure (MPI)].

\section{RESEARCH METHODOLOGY AND ANALYSIS}

The research methodology employed in this study is the Data Envelopment Analysis (DEA) model. DEA is a well-known non-parametric linear programming method for measuring the relative efficiency (Thanassoulis et al., 2011; Bankole et al., 2011c) and has also been used for understanding the impacts of IT investments on performance and productivity (Hatami-Marbini et al., 2010). DEA is a data-oriented method for evaluating the performance (efficiency) of entities known as Decision Making Units (DMUs) (Bankole et al., 2011c) which uses input-output data to compute an efficient production frontier produced by the most efficient DMU's. DEA, unlike a parametric method, is context specific with respect to the interpretations of the results of the analysis, which are restricted to the sample and should not be generalized beyond the sample (Samoilenko \& Osei-Bryson, 2017). DEA, therefore, can then be viewed as a multiple-criteria evaluation methodology where DMUs are alternatives, and DEA inputs and outputs are two sets of performance criteria where one set (inputs) is to be minimized and the other (outputs) is to be maximized (Cook et al., 2014). In DEA, these multiple criteria are generally modelled as in a ratio form, e.g., the CCR ratio model (Charnes et al., 1978; Cook et al., 2014) which is expressed as: 
$\max e_{j o}$

subject to $\mathrm{e}_{\mathrm{j}}<1$

where

$$
\mathrm{e}_{\mathrm{j}}=\frac{\sum_{\mathrm{r}=1}^{\mathrm{s}} \mathrm{u}_{\mathrm{r}} \mathrm{y}_{\mathrm{fj}}}{\sum_{\mathrm{i}=1}^{\mathrm{m}} \mathrm{V}_{\mathrm{i}} \mathrm{X}_{\mathrm{ij}}}
$$

where $x_{i j}$ and $y_{r j}$ represents DEA inputs and outputs, and $v_{i}$ and $u_{r}$ are unknown weights. Although $x_{i j}$ and $y_{r j}$ can be referred to in different terms, rather than "inputs" and "outputs", for this research, ICT Infrastructure serve as the Inputs and Educational Attainment/Adult Literacy rates serve as the Outputs.

The ICT Infrastructure input variables used will be individuals with access to computers, internet and mobile phones. Since the focus of this paper is to measure the relative efficiency of ICT Infrastructure with respect to education only as an aspect of human development, the output variables will therefore be educational attainment from post-secondary level through to bachelors level and adult literacy rates. An Input-Oriented Basic Radial Model (BRM) with Constant Returns to Scale (CRS) DEA approach is used and compared with Input-Oriented BRM with Variable Returns to Scale (VRS) approach for this research. The VRS and CRS models are two conventional choices of a DEA model (Podinovski et al., 2014). The choice of an Input-Oriented BRM is based on the theoretical assumption that the ICT infrastructure (Input) are controllable and increase or decrease in the levels of these inputs is expected to bring about a corresponding increase or decrease in the levels of Educational Attainments and Literacy Rates (Output) respectively for the CRS. Practically, however this may not be the case as effective utilization of the Inputs may or may not be properly controlled and therefore become subjective to particular users and participants. This is where VRS helps us to be able to measure the relative efficiency without assuming the inputs are controllable. The results from these two DEA models are presented and findings discussed. 
For this study, time series data from the United Nations Educational, Scientific and Cultural Organization (UNESCO); educational attainments; World bank; literacy rates and the International Telecommunication Union (ITU); individuals with computers, internet and mobile phones were obtained. Available data was collected for all countries in Sub-Saharan Africa, Northern Africa, and select countries in Europe and Northern America. These were compared with the overall world percentages to measure relative efficiency. Data for the past 7 years, 2011-2017 was collected in percentages of the country population, the ratio values computed, and the average values for the years in the study calculated and used for the values representing each region as shown in Table 1.

Table 1. Regional Data Averages (2011 - 2017) in Ratios to Population

\begin{tabular}{|c|c|c|c|c|c|c|c|}
\hline Regions & $\begin{array}{l}\text { Individuals } \\
\text { using } \\
\text { Computers }\end{array}$ & $\begin{array}{l}\text { Individuals } \\
\text { using } \\
\text { Internet }\end{array}$ & $\begin{array}{l}\text { Individuals } \\
\text { using } \\
\text { Mobile } \\
\text { Phones }\end{array}$ & $\begin{array}{l}\text { Educational } \\
\text { Attainment } \\
\text { (Post- } \\
\text { Secondary) }\end{array}$ & $\begin{array}{l}\text { Educational } \\
\text { Attainment } \\
\text { (Short } \\
\text { Cycle } \\
\text { Tertiary) }\end{array}$ & $\begin{array}{l}\text { Educational } \\
\text { Attainment } \\
\text { (Bachelors) }\end{array}$ & $\begin{array}{l}\text { Adult } \\
\text { Literacy } \\
\text { Rate }\end{array}$ \\
\hline & INPUT & INPUT & INPUT & OUTPUT & OUTPUT & OUTPUT & OUTPUT \\
\hline $\begin{array}{l}\text { Sub- } \\
\text { Saharan } \\
\text { Africa }\end{array}$ & 0.24 & 0.1399 & 0.7495 & 0.1086 & 0.056 & 0.0288 & 0.6287 \\
\hline $\begin{array}{l}\text { Northern } \\
\text { Africa }\end{array}$ & 0.4257 & 0.3004 & 0.8827 & 0.1235 & 0.1327 & N/A & 0.7236 \\
\hline $\begin{array}{l}\text { Europe } \\
\text { and North } \\
\text { America }\end{array}$ & 0.7631 & 0.7074 & 0.9134 & 0.2962 & 0.2539 & 0.2168 & 0.9915 \\
\hline World & 0.61 & 0.4343 & 0.8772 & 0.2695 & 0.2167 & 0.1507 & 0.8559 \\
\hline
\end{tabular}

Table 2 shows statistics of the data being analysed. This is the minimum, maximum, mean and standard deviation values for the data. 
Table 2: Data Statistics

\begin{tabular}{|c|c|c|c|c|}
\hline Index & Minimum & Maximum & Mean & $\begin{array}{l}\text { Standard } \\
\text { Deviation }\end{array}$ \\
\hline Individuals with Computers (Input) & 0.24 & 0.7631 & 0.51 & 0.1963 \\
\hline Individuals with Internet (Input) & 0.1399 & 0.7074 & 0.396 & 0.2081 \\
\hline Individuals with Mobile Phones (Input) & 0.7495 & 0.9134 & 0.856 & 0.0628 \\
\hline $\begin{array}{l}\text { Educational Attainment Post-Secondary } \\
\text { (Output) }\end{array}$ & 0.1086 & 0.2962 & 0.2 & 0.0841 \\
\hline $\begin{array}{l}\text { Educational Attainment Short-cycle Tertiary } \\
\text { (Output) }\end{array}$ & 0.056 & 0.2539 & 0.165 & 0.0766 \\
\hline Educational Attainment Bachelors (Output) & 0 & 0.2168 & 0.099 & 0.0884 \\
\hline Adult Literacy Rates (Output) & 0.6287 & 0.9915 & 0.8 & 0.1369 \\
\hline
\end{tabular}

The Input-Oriented BRM analysis for both the CRS and VRS models of the data collected was calculated using the Data Envelopment Analysis Online Software (D.E.A.O.S.) available online at https://deaos.com . Tables 3 shows the BRM weights for the CRS model analysis on the data collected while Table 4 shows that for the VRS model analysis. For more summaries of the analysis and calculations see Appendix A.

Table 3: Basic Radial Models (Envelopment Forms) Weights - CRS

\begin{tabular}{|c|c|c|c|c|c|c|c|}
\hline Region & $\begin{array}{c}\text { Individuals } \\
\text { with } \\
\text { Computers }\end{array}$ & $\begin{array}{c}\text { Individuals } \\
\text { with } \\
\text { Internet }\end{array}$ & $\begin{array}{c}\text { Individuals } \\
\text { with } \\
\text { Mobile } \\
\text { Phones }\end{array}$ & $\begin{array}{l}\text { Educational } \\
\text { Attainment } \\
\text { Post- } \\
\text { Secondary }\end{array}$ & $\begin{array}{l}\text { Educational } \\
\text { Attainment } \\
\text { short cycle } \\
\text { tertiary }\end{array}$ & $\begin{array}{l}\text { Educational } \\
\text { Attainment } \\
\text { Bachelors }\end{array}$ & $\begin{array}{c}\text { Adult } \\
\text { Literacy } \\
\text { Rates }\end{array}$ \\
\hline $\begin{array}{c}\text { Sub- } \\
\text { Saharan } \\
\text { Africa } \\
\end{array}$ & 3.984 & 0 & 0.058 & 9.208 & 0 & 0 & 0 \\
\hline $\begin{array}{c}\text { Northern } \\
\text { Africa }\end{array}$ & 2.349 & 0 & 0 & 0 & 4.737 & 0 & 0.475 \\
\hline $\begin{array}{c}\text { Europe } \\
\text { and } \\
\text { North } \\
\text { America } \\
\end{array}$ & 1.31 & 0 & 0 & 1.073 & 0 & 2.159 & 0.216 \\
\hline World & 1.605 & 0 & 0.024 & 3.711 & 0 & 0 & 0 \\
\hline
\end{tabular}


Table 4: Basic Radial Models (Envelopment Forms) Weights - VRS

\begin{tabular}{|c|c|c|c|c|c|c|c|}
\hline Region & $\begin{array}{l}\text { Individuals } \\
\text { with } \\
\text { Computers }\end{array}$ & $\begin{array}{c}\text { Individuals } \\
\text { with } \\
\text { Internet }\end{array}$ & $\begin{array}{c}\text { Individuals } \\
\text { with } \\
\text { Mobile } \\
\text { Phones }\end{array}$ & $\begin{array}{c}\text { Educational } \\
\text { Attainment } \\
\text { Post- } \\
\text { Secondary }\end{array}$ & $\begin{array}{l}\text { Educational } \\
\text { Attainment } \\
\text { short cycle } \\
\text { tertiary }\end{array}$ & $\begin{array}{c}\text { Educational } \\
\text { Attainment } \\
\text { Bachelors }\end{array}$ & $\begin{array}{c}\text { Adult } \\
\text { Literacy } \\
\text { Rates }\end{array}$ \\
\hline $\begin{array}{c}\text { Sub- } \\
\text { Saharan } \\
\text { Africa }\end{array}$ & 3.984 & 0 & 0.058 & 9.208 & 0 & 0 & 0 \\
\hline $\begin{array}{c}\text { Northern } \\
\text { Africa }\end{array}$ & 2.349 & 0 & 0 & 0 & 5.409 & 0 & 0 \\
\hline $\begin{array}{l}\text { Europe } \\
\text { and } \\
\text { North } \\
\text { America } \\
\end{array}$ & 1.31 & 0 & 0 & 1.073 & 0 & 2.159 & 0.216 \\
\hline World & 1.605 & 0 & 0.024 & 3.711 & 0 & 0 & 0 \\
\hline
\end{tabular}

\section{DISCUSSION OF FINDINGS}

From the analysis of both models, we can see in table 5, that Northern Africa is $97.2 \%$ and $97.8 \%$ relatively efficient in its utilization of ICT Infrastructure for the educational component of National Development while Sub-Saharan Africa, Europe and North America and the World are optimally relatively efficient. Sub-Saharan Africa has the average lowest percentage of ICT infrastructure utilization, educational attainments and adult literacy rates, however, both models show that it is optimally relatively efficient in its utilization if ICT Infrastructure for education. This supports the notion that should there be in increase in ICT Infrastructure in this region, whether properly controlled or not, there will be a corresponding increase in educational attainment and Adult Literacy rates. This will bring about an increase in quality of life and Human Development with respect to the Nations HDI. Bankole et al., (2011d) stated that the Human Development Index (HDI) is used to assess the quality of life in a nation and is based on three components: Standard of Living, Knowledge Acquisition (education), and Health. For assessing knowledge acquisition capability (education), national literacy rates and levels of school enrolment/attainment are used (UNDP, 1990, 1991, 2006). 


\section{Table 5: Efficiency Summary}

\begin{tabular}{|c|c|c|}
\hline \multicolumn{1}{|c|}{ Region } & Efficiency CRS & \multicolumn{1}{c|}{ Efficiency VRS } \\
$\begin{array}{c}\text { Sub- } \\
\text { Saharan } \\
\text { Africa }\end{array}$ & $100 \%$ & $100 \%$ \\
\hline $\begin{array}{c}\text { Northern } \\
\text { Africa }\end{array}$ & $97.20 \%$ & $97.80 \%$ \\
\hline $\begin{array}{c}\text { Europe and } \\
\text { North } \\
\text { America }\end{array}$ & $100 \%$ & $100 \%$ \\
\hline World & $100 \%$ & $100 \%$ \\
\hline
\end{tabular}

As expected, Europe and North America have the highest average values for ICT Infrastructure utilization, educational attainments and literacy rates and are optimally relatively efficient in this regard. Continuous increase of ICT Infrastructure utilization in education will continue to yield positive results in educational attainment and adult literacy rates. Although Northern Africa have higher average values than Sub-Saharan Africa across most of the indices, the fact that there was no data available for Educational Attainment (Bachelors) may be a mitigating factor against their relative efficiency frontier thus reducing the efficiency value. This is not to say however that Northern Africa is not efficient, but rather has the lowest relative efficiency in this grouping and within the context of the models used.

In comparing the results of the CRS and VRS models of analysis on this data, we see that there is no significant difference in the relative efficiencies of the regions. This therefore means that there is a relatively efficient utilization of ICT infrastructure (Input variables), whether controllable or not, subjective or objective, with respect to educational attainment/adult literacy rates (Output variables). In table 6, we can see that Individuals with computers has the strongest correlation with educational attainment and adult literacy rates while individuals with mobile phones has the weakest correlation. This may also be a strong indication of the outcome of pedagogical changes in teaching and learning over the years which now include higher usage of computers. This would therefore make a strong case for the continued increase in the introduction of online learning and blended learning environments into education. 
Table 6: Correlation between Input and Output Indices

\begin{tabular}{|c|c|c|c|}
\hline Column1 & Individuals with Computers & Individuals with Internet & Individuals with Mobile Phones \\
\hline $\begin{array}{c}\text { Educational } \\
\text { Attainment } \\
\text { Post- } \\
\text { Secondary }\end{array}$ & 0.9456 & 0.905 & 0.6947 \\
\hline $\begin{array}{c}\text { Educational } \\
\text { Attainment } \\
\text { Short-Cycle } \\
\text { Tertiary }\end{array}$ & 0.9942 & 0.951 & 0.8794 \\
\hline $\begin{array}{c}\text { Educational } \\
\text { Attainment } \\
\text { Bachelors }\end{array}$ & 0.8972 & 0.8982 & 0.5709 \\
\hline $\begin{array}{c}\text { Adult } \\
\text { Literacy } \\
\text { Rates }\end{array}$ & 0.9932 & 0.9913 & 0.8246 \\
\hline Average & 0.9576 & 0.9364 & 0.7424 \\
\hline
\end{tabular}

\section{LIMITATIONS}

The main limitation of this study is the availability of the data for the dataset. The data was collected from the United Nations Educational, Scientific and Cultural Organization (UNESCO) educational attainments; World bank - literacy rates and the International Telecommunication Union (ITU) - individuals with computers, internet and mobile phones. Considering that the years being investigated are the most recent and the sources of the data are credible and well cited sources for scientific data collection, some countries within each region did not have data available for one or more years being investigated. This may have positive or negative effects on the regional averages calculated as the data collected is represented as a percentage of the population of the countries. 


\section{CONCLUSION AND FUTURE WORK}

This research has been able to show that existing ICT infrastructure over the past 7 years are being relatively efficiently utilized with respect to educational attainment and adult literacy rates and thus affecting the HDI of the regions being investigated. The research further shows that SubSaharan Africa with significantly lower educational attainment and literacy rates are relatively efficiently utilizing their significantly lower ICT infrastructure and therefore provides an empirical basis for justifying increased spending in ICT infrastructure. Using the CRS and VRS models for the DEA analysis, the research has been able to empirically prove that whether being able to control the inputs (ICT Infrastructure) or not, an increase in the input will bring about a significantly corresponding increase in the output (Educational Attainment / Adult Literacy Rates).

The research has also been able to show that there is a strong correlation between ICT Infrastructure and Educational Attainment / Adult Literacy rates. The correlation is strongest on the individuals with computers index of the ICT Infrastructure as shown in Figure 1. An area of future research would be to investigate this further in order to ascertain whether increased spending in computer hardware and availability of these resources to individuals will have any impact on education considering we have seen how efficiently these ICT infrastructures are currently being utilized. With such a strong correlation, we can, with no scientific basis, understand why there is a call for increased spending on ICT infrastructure for education. Further research will be to investigate whether there is a justification for such spending and what impact it may have on its utilization on the educational component of the Human Development Index. While noting that the strongest correlation occurs between the individuals with computers and educational attainment post-secondary indices, the further research may choose to consider ICT Infrastructure utilization in secondary and post-secondary education as well and not just tertiary education. 
Figure 1: Correlation between Input and Output Indices
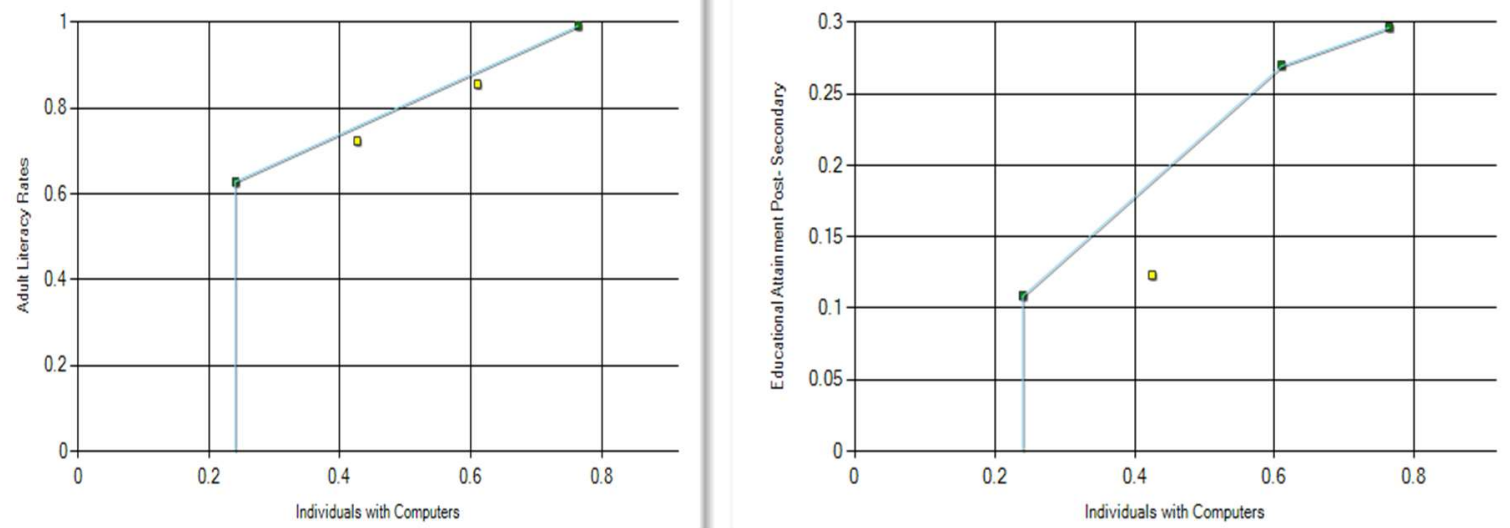

While acknowledging that that DEA as a methodology is context specific and by its very nature of being non-parametric does not allow for generalization, the research has been able to prove that within the sample itself and within the context of educational attainment / adult literacy rates, there is a strong positive impact of ICT on Human Development albeit within the Educational index. An area of future research would be to expand this context by showing how ICT impacts on each of the components of the Human Development Index within the specified DMU's and determine the correlations, if any between them. Also, it would be interesting to see, as m-learning initiatives pick up, whether the correlation between mobile phones and educational attainments and literacy rates will become stronger and what effect(s), if any, this will have on Human Development. 


\section{REFERENCES}

Afonso, A., \& St. Aubyn, M. (2005). Non-parametric approaches to education and health efficiency in Oecd countries. Journal of Applied Economics, 8(2): 227-246.

Afonso, A., \& St. Aubyn, M. (2006a). Cross-country efficiency of secondary education provision: a semiparametric analysis with non-discretionary inputs. Economic Modelling, 23(3): 476-491.

Afonso, A., \& St. Aubyn, M. (2006b). Relative efficiency of health provision: a DEA approach with nondiscretionary inputs. ISEG-UTL, Department of Economics Working Paper $n^{o}$ 33/2006/DE/UECE.

Akpan, P. (2000) Africa and the New ICTs: Implications for Development. Proceedings of the International Federation for Processing Conference (IFIP TC9), South Africa.

Anand, S., \& Ravallion, M. (1993). Human Development in Poor Countries: On the Role of Private Incomes and Public Services. The Journal of Economic Perspective, 7(1), 133-150.

Angulo-Meza, L., \& Lins, M. P. E. (2002). Review of methods for increasing discrimination in data envelopment analysis. Annals of Operations Research, 116(1-4), 225-242.

Arcelus, F. J., \& Coleman, D. F. (1997). An efficiency review of university departments. International Journal of Systems Science, 28(7), 721-729.

Aristovnik, A. (2012). The impact of ICT on educational performance and its efficiency in selected EU and OECD countries: a non-parametric analysis. Available at SSRN: https://ssrn.com/abstract=2187482 or http://dx.doi.org/10.2139/ssrn.2187482

Atici, K. B., \& Podinovski, V. V. (2015). Using data envelopment analysis for the assessment of technical efficiency of units with different specialisations: An application to agriculture. Omega, 54, 72-83.

Avkiran, N. K. (2001). Investigating technical and scale efficiencies of Australian universities through data envelopment analysis. Socio-Economic Planning Sciences, 35(1), 57-80.

Bankole, F. O., Shirazi, F., \& Brown, I. (2011a). Investigating the impact of ICT investments on human development. The Electronic Journal of Information Systems in Developing Countries, 48(1), 1-19.

Bankole, F. O., Brown, I., \& Osei-Bryson, K. M. (2011b). The Impact of ICT Infrastructure on Human Development: An Analysis of ICT-Use in SADC Countries. In Proceedings of the 11th International Conference on Social Implications of Computers in Developing Countries, Kathmandu, Nepal, May 2011

Bankole, F. O., Osei-Bryson, K. M., \& Brown, I. (2011c). ICT infrastructure utilization in Africa: Data envelopment analysis based exploration. In Proceeding of special interest group on ICT and global development at Americas Conference on Information System (AMCIS) Workshop, Detroit, USA.

Bankole, F. O., Osei-Bryson, K. M., \& Brown, I. (2011d). Exploring the Impacts of ICT Investments on Dimensions of Human Development in Different Contexts: A Regression Splines Analysis. In Proceedings of SIG GlobDev Fourth Annual Workshop (Vol. 158).

Bankole, F. O., Osei-Bryson, K. M., \& Brown, I. (2013). The impact of ICT investments on human development: A regression splines analysis. Journal of Global Information Technology Management, 16(2), 59-85.

Bankole, F.O (2015). ICT Infrastructure and Its' Impact on National Development: A Research Direction for Africa Using Analytics. In Proceedings of SIG GlobDev 2015 Pre-ECIS Workshop, Munster, Germany, May 26, 2015. 
Bankole Dr, F., \& Mimbi, L. (2017). ICT Infrastructure and It's Impact on National Development: A Research Direction for Africa. The African Journal of Information Systems, 9(2), 1.

Bessent, A. M., \& Bessent, E. W. (1980). Determining the comparative efficiency of schools through data envelopment analysis. Educational Administration Quarterly, 16(2), 57-75.

Bessent, A., Bessent, W., Kennington, J., \& Reagan, B. (1982). An application of mathematical programming to assess productivity in the Houston independent school district. Management Science, 28(12), 1355-1367.

Bessent, A. M., Bessent, E. W., Charnes, A., Cooper, W. W., \& Thorogood, N. C. (1983). Evaluation of educational program proposals by means of DEA. Educational Administration Quarterly, 19(2), 82-107.

Bradley, S., Johnes, G., \& Millington, J. (2001). The effect of competition on the efficiency of secondary schools in England. European Journal of Operational Research, 135(3), 545-568.

Charnes, A., Cooper, W. W., \& Rhodes, E. (1978). Measuring the efficiency of decision making units. European journal of operational research, 2(6), 429-444.

Charnes, A., Cooper, W. W., \& Rhodes, E. (1981). Evaluating program and managerial efficiency: an application of data envelopment analysis to program follow through. Management science, 27(6), 668-697.

Clements, B. (2002). How efficient is education spending in Europe? European Review of Economics and Finance, 1: 3-26.

Cook, W. D., Tone, K., \& Zhu, J. (2014). Data envelopment analysis: Prior to choosing a model. Omega, 44, 1-4.

Cooper, W. W., Seiford, L. M., \& Tone, K. (2006). Introduction to data envelopment analysis and its uses. New York: Springer.

Cooper, WW, Seiford, LM and Tone, K. (2007). Data Envelopment Analysis: A Comprehensive Text with Models, Applications, References and DEA-Solver Software.

Desai, M. (1991). Human development. European Economic Review, 35(2-3), 350-357. doi:10.1016/0014-2921(91)90136-7

Färe, R., Grosskopf, S., Forsund, F. R., Hayes, K., \& Heshmati, A. (2006). Measurement of productivity and quality in non-marketable services: with application to schools. Quality Assurance in Education, 14(1), 21-36.

Grosskopf, S., \& Moutray, C. (2001). Evaluating performance in Chicago public high schools in the wake of decentralization. Economics and Education Review, 20, 1-14.

Gülbahar, Y., (2008). ICT usage in higher education: a case study on preservice teachers and instructors, The Turkish Online Journal of Educational Technology, 7(1): 32-37.

Gupta, S., \& Verhoeven, M. (2001). The efficiency of government expenditure: experiences from Africa. Journal of policy modeling, 23(4), 433-467.

Hatami-Marbini, A., Saati, S., \& Tavana, M. (2010). An ideal-seeking fuzzy data envelopment analysis framework. Applied Soft Computing, 10(4), 1062-1070.

Hinostroza, J. E., Isaacs, S., \& Bougroum, M. (2014). Information and communications technologies for improving learning opportunities and outcomes in developing countries. In Learning and education in developing countries: Research and policy for the post-2015 UN development goals (pp. 42-57). Palgrave Pivot, New York.

Hinostroza, J. E. (2018). New Challenges for ICT in Education Policies in Developing Countries: The Need to Account for the Widespread Use of ICT for Teaching and Learning 
Outside the School. In ICT-Supported Innovations in Small Countries and Developing Regions (pp. 99-119). Springer, Cham.

Johnes, J. (2006). Data envelopment analysis and its application to the measurement of efficiency in higher education. Economics of Education Review, 25(3), 273-288.

Johnes, J., \& Li, Y. U. (2008). Measuring the research performance of Chinese higher education institutions using data envelopment analysis. China economic review, 19(4), 679-696.

Liu, J. S., Lu, L. Y., Lu, W. M., \& Lin, B. J. (2013a). Data envelopment analysis 1978-2010: A citation-based literature survey. Omega, 41(1), 3-15.

Liu, J. S., Lu, L. Y., Lu, W. M., \& Lin, B. J. (2013b). A survey of DEA applications. Omega, 41(5), 893-902.

Neumayer, E. (2001). The human development index and sustainability - a constructive proposal. Ecological Economics, 39(1), 101-114.

Olaniyi, T. K., \& Ademola, O. E. (2013). Integrating Information Communication and Technology into Classroom in Higher Education. Available online at: https://s3.amazonaws.com/academia.edu.documents/36221428/Integrating_ICT_in_a_Class Room_Learning_Environment.pdf?AWSAccessKeyId=AKIAIWOWYYGZ2Y $53 \overline{\text { UL }}$ 3A\& Expires $=1541762737 \&$ Signature $=I 5 F 69$ AAZL95mY\%2BKVmVpLAurK2jc\%3D\&response -contentdisposition=inline $\% 3 \mathrm{~B} \% 20$ filename $\% 3$ DIntegrating_Information_Communication_an.pdf

Orbicom (2005) From The Digital Divide To Digital Opportunities: Measuring Infostates for Development, Montreal: Claude-Yves Charron.

Oyerinde, O. D., \& Chia, P. A. (2017). Predicting students' academic performances-A learning analytics approach using multiple linear regression. International Journal of Computer Applications, 157(4).

Podinovski, V. V., \& Thanassoulis, E. (2007). Improving discrimination in data envelopment analysis: Some practical suggestions. Journal of Productivity Analysis, 28(1-2), 117-126.

Podinovski, V. V., Ismail, I., Bouzdine-Chameeva, T., \& Zhang, W. (2014). Combining the assumptions of variable and constant returns to scale in the efficiency evaluation of secondary schools. European Journal of Operational Research, 239(2), 504-513.

Portela, M. C. S., Camanho, A. S., \& Borges, D. (2012). Performance assessment of secondary schools: the snapshot of a country taken by DEA. Journal of the Operational Research Society, 63(8), 1098-1115.

Samoilenko, S. V., \& Osei-Bryson, K. M. (2017). Creating Theoretical Research Frameworks Using Multiple Methods: Insight from ICT4D Investigations. Auerbach Publications.

Sinuany-Stern, Z., Mehrez, A., \& Barboy, A. (1994). Academic departments efficiency via DEA. Computers \& Operations Research, 21(5), 543-556.

St Aubyn, M. (2002). Evaluating efficiency in the Portuguese health and education sectors. Economia, Vol. 26. Available at SSRN: https://ssrn.com/abstract=504942

Thanassoulis, E., Portela, M. C., \& Despic, O. (2008). Data envelopment analysis: the mathematical programming approach to efficiency analysis. The measurement of productive efficiency and productivity growth, 251-420.

Thanassoulis, E., Kortelainen, M., Johnes, G., \& Johnes, J. (2011). Costs and efficiency of higher education institutions in England: A DEA analysis. Journal of the Operational Research Society, 62, 1282-1297.

Tondeur, J., van Braak, J., \& Valcke, M. (2007). Towards a typology of computer use in primary education. Journal of Computer Assisted Learning, 23, 197-206. 
UNDP: United Nations Development Programme. (2006). The Millennium Development Goals. UNDP. 


\section{APPENDIX A}

Table A1: Summary for Sub-Saharan Africa

\begin{tabular}{|c|c|c|c|c|c|c|c|}
\hline & $\begin{array}{c}\text { Individuals } \\
\text { with } \\
\text { Computers }\end{array}$ & $\begin{array}{c}\text { Individuals } \\
\text { with } \\
\text { Internet }\end{array}$ & $\begin{array}{c}\text { Individuals } \\
\text { with } \\
\text { Mobile } \\
\text { Phones }\end{array}$ & $\begin{array}{c}\text { Educational } \\
\text { Attainment } \\
\text { Post- } \\
\text { Secondary }\end{array}$ & $\begin{array}{l}\text { Educational } \\
\text { Attainment } \\
\text { short cycle } \\
\text { tertiary }\end{array}$ & $\begin{array}{l}\text { Educational } \\
\text { Attainment } \\
\text { Bachelors }\end{array}$ & $\begin{array}{c}\text { Adult } \\
\text { Literacy } \\
\text { Rates }\end{array}$ \\
\hline Slacks & 0 & 0 & 0 & 0 & 0 & 0 & 0 \\
\hline Weights & 3.984 & 0 & 0.058 & 9.208 & 0 & 0 & 0 \\
\hline Values & 0.24 & 0.14 & 0.75 & 0.109 & 0.056 & 0.029 & 0.629 \\
\hline Targets & 0.24 & 0.14 & 0.75 & 0.109 & 0.056 & 0.029 & 0.629 \\
\hline
\end{tabular}

Table A2: Summary for Northern Africa

\begin{tabular}{|c|c|c|c|c|c|c|c|}
\hline & $\begin{array}{c}\text { Individuals } \\
\text { with } \\
\text { Computers }\end{array}$ & $\begin{array}{c}\text { Individuals } \\
\text { with } \\
\text { Internet }\end{array}$ & $\begin{array}{c}\text { Individuals } \\
\text { with } \\
\text { Mobile } \\
\text { Phones }\end{array}$ & $\begin{array}{l}\text { Educational } \\
\text { Attainment } \\
\text { Post- } \\
\text { Secondary }\end{array}$ & $\begin{array}{l}\text { Educational } \\
\text { Attainment } \\
\text { short cycle } \\
\text { tertiary }\end{array}$ & $\begin{array}{c}\text { Educational } \\
\text { Attainment } \\
\text { Bachelors }\end{array}$ & $\begin{array}{c}\text { Adult } \\
\text { Literacy } \\
\text { Rates }\end{array}$ \\
\hline Slacks & 0 & 0.013 & 0.065 & 0.061 & 0 & 0.087 & 0 \\
\hline Weights & 2.349 & 0 & 0 & 0 & 4.737 & 0 & 0.475 \\
\hline Values & 0.426 & 0.3 & 0.883 & 0.124 & 0.133 & 0 & 0.724 \\
\hline Targets & 0.414 & 0.279 & 0.793 & 0.184 & 0.133 & 0.087 & 0.724 \\
\hline
\end{tabular}

Table A3: Summary for Europe and North America

\begin{tabular}{|c|c|c|c|c|c|c|c|}
\hline & $\begin{array}{l}\text { Individuals } \\
\text { with } \\
\text { Computers }\end{array}$ & $\begin{array}{c}\text { Individuals } \\
\text { with } \\
\text { Internet }\end{array}$ & $\begin{array}{c}\text { Individuals } \\
\text { with } \\
\text { Mobile } \\
\text { Phones }\end{array}$ & $\begin{array}{l}\text { Educational } \\
\text { Attainment } \\
\text { Post- } \\
\text { Secondary }\end{array}$ & $\begin{array}{l}\text { Educational } \\
\text { Attainment } \\
\text { short cycle } \\
\text { tertiary }\end{array}$ & $\begin{array}{l}\text { Educational } \\
\text { Attainment } \\
\text { Bachelors }\end{array}$ & $\begin{array}{c}\text { Adult } \\
\text { Literacy } \\
\text { Rates }\end{array}$ \\
\hline Slacks & 0 & 0 & 0 & 0 & 0 & 0 & 0 \\
\hline Weights & 1.31 & 0 & 0 & 1.073 & 0 & 2.159 & 0.216 \\
\hline Values & 0.763 & 0.707 & 0.913 & 0.296 & 0.254 & 0.217 & 0.992 \\
\hline Targets & 0.763 & 0.707 & 0.913 & 0.296 & 0.254 & 0.217 & 0.992 \\
\hline
\end{tabular}


Table A4: Summary for World

\begin{tabular}{|c|c|c|c|c|c|c|c|}
\hline & $\begin{array}{l}\text { Individuals } \\
\text { with } \\
\text { Computers }\end{array}$ & $\begin{array}{c}\text { Individuals } \\
\text { with } \\
\text { Internet }\end{array}$ & $\begin{array}{c}\text { Individuals } \\
\text { with } \\
\text { Mobile } \\
\text { Phones }\end{array}$ & $\begin{array}{l}\text { Educational } \\
\text { Attainment } \\
\text { Post- } \\
\text { Secondary }\end{array}$ & $\begin{array}{l}\text { Educational } \\
\text { Attainment } \\
\text { short cycle } \\
\text { tertiary }\end{array}$ & $\begin{array}{l}\text { Educational } \\
\text { Attainment } \\
\text { Bachelors }\end{array}$ & $\begin{array}{c}\text { Adult } \\
\text { Literacy } \\
\text { Rates }\end{array}$ \\
\hline Slacks & 0 & 0 & 0 & 0 & 0 & 0 & 0 \\
\hline Weights & 1.605 & 0 & 0.024 & 3.711 & 0 & 0 & 0 \\
\hline Values & 0.61 & 0.434 & 0.877 & 0.27 & 0.217 & 0.151 & 0.856 \\
\hline Targets & 0.61 & 0.434 & 0.877 & 0.27 & 0.217 & 0.151 & 0.856 \\
\hline
\end{tabular}

Table A5: Summary for Northern Africa - VRS with Difference Highlighted

\begin{tabular}{|c|c|c|c|c|c|c|c|}
\hline & $\begin{array}{c}\text { Individuals } \\
\text { with } \\
\text { Computers }\end{array}$ & $\begin{array}{c}\text { Individuals } \\
\text { with } \\
\text { Internet }\end{array}$ & $\begin{array}{c}\text { Individuals } \\
\text { with } \\
\text { Mobile } \\
\text { Phones }\end{array}$ & $\begin{array}{l}\text { Educational } \\
\text { Attainment } \\
\text { Post- } \\
\text { Secondary }\end{array}$ & $\begin{array}{c}\text { Educational } \\
\text { Attainment } \\
\text { short cycle } \\
\text { tertiary }\end{array}$ & $\begin{array}{l}\text { Educational } \\
\text { Attainment } \\
\text { Bachelors }\end{array}$ & $\begin{array}{c}\text { Adult } \\
\text { Literacy } \\
\text { Rates }\end{array}$ \\
\hline Slacks & 0 & 0.014 & 0.053 & 0.062 & 0 & 0.087 & 0.014 \\
\hline Weights & 2.349 & 0 & 0 & 0 & 5.409 & 0 & 0 \\
\hline Values & 0.426 & 0.3 & 0.883 & 0.124 & 0.133 & 0 & 0.724 \\
\hline Targets & 0.417 & 0.279 & 0.81 & 0.185 & 0.133 & 0.087 & 0.737 \\
\hline
\end{tabular}

